\title{
PARADIGMA PENDIDIKAN SENI DI ERA GLOBALISASI BERBASIS WACANA
}

\author{
Oleh: \\ Arya Pageh Wibawa \\ Institut Seni Indonesia Denpasar \\ e-mail: pageh.wibawa@gmail.com
}

\begin{abstract}
The paradigm of the arts education in the future must be able to apply various approaches where learners can cultivate their views and tolerant attitude towards the cultural diversity in Indonesia. The arts education is expected to be a compulsory course in universities so that the students have sensitive, aesthetic, creative and innovative attitude as well as adaptive character to any change and good ethics in expressing their creativities. It is not just an education generated only for the sake of art competition but must become a daily necessity. In facing the globalization phenomenon, the arts education is made to utilize multicultural approach which can be accepted by various circles of society. The arts education with a multicultural approach should have flexibility and rely on the ability of the learners and the socio-cultural conditions of the local society. The role of the arts educators is expected to not only possess the local artistic knowledge, but also the knowledge about other regional arts so that in this way the students obtain complete knowledge of arts and culture as well as fostering the sense of tolerance with the diversity.
\end{abstract}

Keywords: Paradigm, Art Education, Critical Discourse Analysis

\begin{abstract}
Abstrak
Paradigma pendidikan seni ke depan diharapkan mampu menggunakan berbagai pendekatan dimana peserta didik dapat menumbuhkembangkan pandangan dan sikap toleran terhadap keberagaman budaya di Indonesia. Pendidikan seni diharapkan menjadi mata kuliah yang wajib diberikan di perguruan tinggi agar mahasiswa memiliki sikap peka rasa, estetika, kreatif dan inovatif serta memiliki karakter yang adaptif terhadap perubahan dan memiliki etika dalam berkarya.

Pendidikan seni bukan hanya pendidikan yang ada hanya karena kebutuhan lomba seni saja tetapi sudah menjadi kebutuhan sehari-hari. Menghadapi globalisasi yang terjadi, pendidikan seni diarahkan pada pendekatan multikultural sehingga bisa diterima oleh berbagai kalangan masyarakat.

Pendidikan seni dengan pendekatan multikultural harus memiliki keluwesan dan bergantung pada kemampuan peserta didik dan kondisi sosial budaya masyarakat setempat. Peran pendidik seni diharapkan tidak hanya memiliki pengetahuan seni lokal saja, tetapi juga memiliki pengetahuan tentang seni daerah lain sehingga mahasiswa memiliki pengetahuan yang lengkap tentang seni dan budaya dan toleransi dengan keberagaman.
\end{abstract}

Kata kunci: Paradigma, Pendidikan Seni, Analisa Wacana Kritis

\section{PENDAHULUAN}

\subsection{Latar Belakang}

Pendidikan merupakan sebuah bagian yang tidak dapat dipisahkan dalam kehidupan manusia. Pendidikan memegang peranan begitu penting dalam meningkatkan harkat dan martabat manusia. Saat ini, kemajuan pendidikan menjadi 
sebuah ukuran kemajuan sebuah bangsa. Sehingga banyak bangsa-bangsa di dunia berusaha terus menerus untuk meningkatkan mutu pendidikannya.

Undang-undang nomor 12 tahun 2012 tentang pendidikan tinggi pada pasal 1 menyatakan bahwa pendidikan adalah usaha sadar dan terencana untuk mewujudkan suasana belajar dan proses pembelajaran agar peserta didik secara aktif mengembangkan potensi dirinya untuk memiliki kekuatan spiritual keagamaan, pengendalian diri, kepribadian, kecerdasan, akhlak mulia, serta keterampilan yang diperlukan dirinya, masyarakat, bangsa, dan negara.

Menurut Ki Hajar Dewantoro, pendidikan adalah daya upaya untuk memajukan bertumbuhnya budi pekerti (kekuatan batin karakter), pikiran (intelek), dan tubuh anak. Ketiga-tiganya tidak boleh dipisah-pisahkan, agar supaya kita dapat memajukan kesempurnaan hidup, kehidupan dan penghidupan anak-anak didik selaras dengan dunianya. Menurut Liliweri (2015: 82), pendidikan dalam artian umum merupakan suatu bentuk pembelajaran pengetahuan, keterampilan, dan kebiasaan dari sekelompok orang dipindahkan dari satu generasi ke generasi berikutnya melalui proses atau kegiatan pengajaran, pelatihan, penelitian, atau hanya melalui otodidak (belajar sendiri). Umumnya pendidikan itu terjadi melalui pengalaman peralihan informasi yang memiliki efek formatif pada cara orang berpikir, merasa, atau tindakan tertentu. Berdasarkan pengertian di atas maka dapat diambil kesimpulan: pendidikan merupakan sebuah usaha sadar untuk mengubah sikap dan mengembangkan potensi peserta didik.

Pendidikan seni yang diajarkan di perguruan tinggi memiliki tantangan yang cukup besar akibat perkembangan ilmu pengetahuan, teknologi, dan seni. Hal ini menjadi permasalahan utama dan tantangan baru bagi para akademisi seni perguruan tinggi. Globalisasi juga memberikan dampak cukup besar terhadap perkembangan seni dan pendidikan seni dimana pendidikan seni harus berbasis pada ethnoscapes, mediascapes, technoscapes, financescapes, dan ideoscapes.

Dengan, rumusan masalah dapat diajukan: Bagaimana paradigma pendidikan seni di perguruan tinggi berbasis pada wacana?

\subsection{Metode}

Tujuan dari penelitian ini adalah untuk meli- hat paradigma pendidikan seni di perguruan tinggi berbasis pada wacana-wacana yang ada baik melalui media cetak maupun media online.

Pada penelitian ini menggunakan metode kualitatif deskriptif dengan memberikan gambaran secara kualitatif tentang paradigma pendidikan seni ke depan dengan menggunakan teknik dokumentasi dari sumber data sekunder dari media cetak maupun media online. Analisa yang digunakan adalah analisis wacana kritis (AWK) dengan menggunakan teori Norman Fairclough.

\subsection{Tinjauan Pustaka \\ 1.3.1. Paradigma}

Berdasarkan Kamus Besar Bahasa Indonesia, kata "paradigma" memiliki pengertian (1) Model dalam teori ilmu; (2) Kerangka berpikir. Secara etimologis, istilah paradigma pada dasarnya berasal dari bahasa Yunani yaitu dari kata " $p a-$ $r a$ " yang artinya di sebelah atau pun di samping, dan kata "diegma" artinya teladan, ideal, model, atau pun arketif. Sedangkan secara terminologis, istilah paradigma diartikan sebagai sebuah pandangan atau pun cara pandang yang digunakan untuk menilai dunia dan alam sekitarnya, merupakan gambaran atau pun perspektif umum berupa cara-cara untuk menjabarkan berbagai macam permasalahan dunia nyata yang sangat kompleks (https://pengertiandefinisi.com/pengertian-paradigma, diakses 21/3/2017). Beberapa pengertian lain kata paradigma adalah sebagai berikut (http://elanurlaela.blogspot.co.id/2011/03/pengertian-paradigma.html, diakses tanggal 21 Maret 2017):

1. Pengertian paradigma menurut Patton (1975): "A world view, a general perspective, a way of breaking down of the complexity of the real world" (suatu pandangan dunia, suatu cara pandang umum, atau suatu cara untuk menguraikan kompleksitas dunia nyata).

2. Pengertian paradigma menurut Robert Friedrichs (1970): Suatu pandangan yang mendasar dari suatu disiplin ilmu tentang apa yang menjadi pokok persoalan yang semestinya dipelajari.

3. Pengertian paradigma menurut George Ritzer (1980): Pandangan yang mendasar dari para ilmuwan tentang apa yang menjadi pokok persoalan yang se- 
mestinya dipelajari oleh salah satu cabang atau disiplin ilmu pengetahuan. Lebih lanjut Ritzer mengungkapkan bahwa paradigma membantu merumuskan tentang apa yang harus dipelajari, persoalan-persoalan yang harus dijawab, bagaimana harus menjawabnya, serta aturan-aturan apa yang harus diikuti dalam menginterpretasikan informasi yang harus dikumpulkan informasi yang dikumpulkan dalam menjawab persoalan-persoalan tersebut.

\subsubsection{Pendidikan Seni}

Pendidikan seni terbagi menjadi dua kata "pendidikan" dan "seni". Pengertian pendidikan telah dijelaskan diatas adalah sebuah usaha sadar untuk mengubah sikap dan mengembangkan potensi peserta didik. Pendidikan secara umum berfungsi untuk mengembangkan kemampuan setiap anak menemukan pemenuhan dirinya dalam hidup, untuk mentransmisikan warisan budaya, memperluas kesadaran sosial dan sebagai jalan untuk menambah pengetahuan.

Kata "seni" telah umum dipakai sebagai padanan kata Inggris "Art". Kata seni berasal dari bahasa Melayu (atau Melayu-Tinggi untuk membedakannya dengan bahasa Melayu-Rendah di zaman kolonial), yang berarti "kecil". Pada tahun 1936, dalam sajaknya "Sesudah Dibajak", Sutan Takdir Alisyahbana masih mempergunakan kata seni dalam pengertian kecil tadi (Sedih seni mengiris kalbu). Dan pada tahun 1941, Taslim Ali juga masih mempergunakan kata seni dalam pengertian "kecil" dalam sajaknya "Kepada Murai" (Hiburkan hati/Unggasku seni). Seni juga dapat diartikan sebagai ketrampilan (skill), aktivitas manusia, karya (work of art), seni indah (fine art), dan seni rupa (visual art). Itulah sebabnya orang dapat berbicara tentang seni pengobatan, seni memasak, seni perang, seni berdagang, seni manajemen. Bahkan seluruh hidup kita ini juga suatu "seni" (Sumardjo, 2000: 41-42).

Pendidikan seni dapat diartikan sebagai usaha yang dilakukan secara sadar untuk mengubah sikap dan mengembangkan potensi ketrampilan, karya, seni indah, dan seni rupa. Menurut Zakarias Sukarya Soetedja (dalam UPI, 2007: 413), Pendidikan seni pada hakekatnya merupakan proses pembentukan manusia me- lalui seni. Tujuan pendidikan seni sejalan dengan tanggung jawab yang luas dari pendidikan secara umum. Program seni di sekolah memfasilitasi siswanya menyediakan kesempatan bagi pemenuhan dirinya melalui pengalaman berkesenian berdasarkan sesuatu yang dekat dengan kehidupan dan dunianya. Pendidikan seni memberikan kontribusi kepada pembentukan sikap pembelajaran seumur hidup, pemahaman dan penghargaan terhadap berbagai perbedaan, serta mendukung kemampuan dasar kecakapan hidup, literasi, numerasi, dan perspektif masa depan.

\subsubsection{Analisa Wacana Kritis}

Kata "wacana" dalam Kamus Besar Bahasa Indonesia (KBBI) memiliki arti (1) ucapan, tutur, percakapan; (2) keseluruhan perkataan atau ucapan yang merupakan suatu kesatuan; (3) satuan bahasa terlengkap, realisasinya tampak pada bentuk karangan yang utuh, seperti novel buku, atau artikel, pada pidato atau khotbah; (4) kemampuan dan prosedur berpikir yang sistematis; (5) pertukaran ide secara verbal. Menurut Hawtan (dalam Badara, 2012:16), menyatakan wacana adalah komunikasi kebahasaan yang terlibat sebagai sebuah pertukaran diantara pembicara dan pendengar, sebagai sebuah aktivitas personal dimana bentuknya ditentukan oleh tujuan sosialnya. Roger Fowler (dalam Badara, 2012:16) berpendapat bahwa wacana adalah komunikasi lisan atau tulisan yang dilihat dari titik pandang kepercayaan, nilai dan kategori yang masuk didalamnya; kepercayaan disini mewakili pandangan dunia; sebuah organisasi atau representasi dari pengalaman. Pandangan-pandangan diatas dapat disimpulkan bahwa wacana adalah representasi dari pengalaman berbentuk ucapan atau perkataan sebagai alat komunikasi baik lisan maupun tertulis sebagai tujuan sosialnya.

Analisis wacana kritis (critical discourse analysis) merupakan metode baru di dalam penelitian ilmu-ilmu sosial dan budaya. Menurut Wodak \& Meyer (dalam Haryatmoko, 2016:1), analisis wacana kritis menerima tiga postulat : (1) semua pendekatan harus berorientasi ke masalah sosial, maka menuntut pendekatan lintasilmu; (2) keprihatinan utama adalah mendemistifikasi ideologi dan kekuasaan melalui penelitian sistemik data semiotik (tulisan, lisan atau visual); (3) selalu reflektif dalam proses peneli- 
tian, artinya mengambil jarak untuk memeriksa nilai dan ideologi peneliti. Fairclough (dalam Haryatmoko, 2016:19) menawarkan empat langkah metode analisis wacana kritis yaitu: (1) memfokuskan pada suatu "ketidakberesan sosial”, dalam aspek semiotiknya; (2) mengidentifikasi hambatan-hambatan untuk menangani "ketidakberesan sosial" itu;(3) mempertimbangkan apakah tatanan sosial itu "membutuhkan" ketidakberesan sosial tersebut;(4) mengidentifikasi cara-cara yang mungkin untuk mengatasi hambatan-hambatan itu. Menurut Fairclough (dalam Haryatmoko, 2016:23), analisis wacana kritis harus memperhatikan tiga dimensinya yaitu teks, praktik diskursif, dan praksis sosial. Teks yaitu semua yang mengacu ke wicara, tulisan, grafik, dan kombinasinya atau semua bentuk linguistik teks (khasanah kata, gramatika, syntax, struktur metafora, retorika).

Praktik diskursif yaitu semua bentuk produksi dan konsumsi teks. Dalam dimensi ini ada proses menghubungkan produksi dan konsumsi teks atau sudah ada interpretasi. Fokusnya diarahkan pada cara pengarang teks mengambil wacana dan genre yang ada dengan memerhatikan bagaimana hubungan kekuasaan dimainkan. Praksis sosial biasanya tertanam dalam tujuan, jaringan dan praksis budaya sosial budaya yang luas. Dalam dimensi ini, sudah mulai masuk pemahaman intertekstual, peristiwa sosial dimana kelihatan bahwa teks dibentuk oleh dan membentuk praksis sosial.

\section{PEMBAHASAN}

\subsection{Teks}

Berdasarkan Badan Nasional Standar Pendidikan (BNSP) tentang paradigma pendidikan abad XXI dikatakan bahwa pengembangan paradigma pendidikan nasional mesti dikaitkan dengan falsafah pendidikan progresif yang menekankan pada pentingnya peran serta aktif para pembelajar (the learners) dalam penetapan tujuan yang mengarahkan segenap aktivitas mereka masing-masing dalam keseluruhan proses pembelajaran, menuju tercapainya kedamaian, kesejahteraan, dan kebahagiaan (BNSP, 2010: 37).

Pada awalnya, pengembangan pendidikan bermuara pada sains, teknologi, dan ekonomi sebagai hal utama sedangkan etika dan estetika kurang mendapatkan perhatian sehingga terli- hat bahwa pendidikan di Indonesia lebih menekankan pada aspek intelektualitas dibandingkan moralitas dan memberikan dampak yang kurang baik bagi peserta didik. Pendidikan lebih berkutat pada pemenuhan kepentingan pasar dan industri, ketimbang pengembangan karakter dan kearifan.

Pendidikan seni yang diajarkan memiliki tujuan untuk mengembangkan pengalaman estetis sehingga pengajaran yang diberikan tidak hanya terbatas pada pengajaran praktek atau pelatihan ketrampilan. Menurut Harry Broudy (dalam Elliot, 1995: 27), konsep estetis dalam pendidikan musik terletak pada pengalaman estetis. Karena dalam pengalaman estetis kita dapat merasakan objek dan memahami karakteristiknya. Pendidikan seni merupakan pemahaman estetika (keindahan) dan pengungkapan kembali estetika dalam sebuah karya seni. Memahami estetika merupakan peristiwa memasukkan estetika melalui pengindraan rasa dan pikir untuk mengobyektifikasikan (http://seputarpengertian.blogspot.co.id/2017/02/pengertian-pendidikan-seni-serta-tujuannya.html, diakses 26/3/2017). Menurut Yakob Soemardjo (2000: 161), pengalaman seni atau estetis adalah pengalaman yang dialami oleh penikmat seni atau penanggap seni.

Pengalaman seni juga merupakan suatu pengalaman utuh yang melibatkan perasaan, pikiran, penginderaan, dan berbagai intuisi manusia. Hanya saja pengalaman seni berlangsung dalam kualitas pengalaman tertentu yang kadang-kadang tidak sama dengan pengalaman sehari-hari. Dalam pengalaman seni, unsur perasaan merupakan kekuatan utama yang menggerakkan dan mendasari unsur-unsur potensi manusia yang lain. Pebelajar seumur hidup yang dibentuk melalui pendidikan seni memiliki karakteristik: berpengetahuan dengan pemahaman yang mendalam; pemikir yang kompleks; kreator responsif; penyelidik aktif; komunikator efektif; partisipan dalam dunia yang saling ketergantungan serta pelajar mandiri dan reflektif (QSCC, 2002).

Pendidikan seni memberikan jalan kepada para siswa untuk memperoleh pengetahuan, keterampilan dan praktek yang spesifik untuk masing-masing disiplin seni. Sesuai dengan kemampuannya, para siswa belajar menggunakan sistem simbol melalui visual, kinestetik dan auditori, bahasa, bentuk dan proses untuk me- 
nyatakan gagasan dan perasaan. Pendidikan seni memberikan arti penting tertentu pada para siswa untuk mengembangkan proses dan keterampilan. Pendidikan seni memberikan kepada para siswa cara untuk mengembangkan suatu kemampuan untuk berpikir secara induktif, deduktif, abduktif, dan intuitif dengan menggunakan dan mencerminkan melalui pengalaman (berkarya dan atau mengapresiasi) seni. Para siswa belajar untuk menyaring pemahaman konseptual mereka, memecahkan permasalahan, membuat pertimbangan, mendiskusikan dan menilai pendapat dengan sikap saling menghargai. Para siswa belajar untuk memahami dan menghargai produk dan proses dari cara berpikir lateral, dan menerapkan strategi (memunculkan dan mengembangkan kreativitas) tersebut untuk memecahkan masalah mereka sendiri.

Pendidikan seni juga memberikan akses terhadap pemikiran dan pengetahuan yang saling berhubungan melalui aktivitas seni. Para siswa mengembangkan perspektif pribadi dan kepekaan yang dimiliki kepada dimensi fisik yang estetis, lingkungan rohani dan budaya. Para siswa akan menjadi paham terhadap gaya belajar mereka sendiri, mengembangkan disiplin diri untuk bekerja dengan bebas, dan gigih terhadap tantangan pekerjaan, untuk merencanakan serta mengakomodasi kemungkinan yang tidak terduga. Pendidikan seni memberikan peluang kepada siswa untuk belajar cara mengatur emosi didalam suatu lingkungan yang mendukung dan aman. Para siswa juga diberikan pengenalan dan penggunaan kelemahan dan kekuatan yang dimiliki serta mengakumulasikan keterampilannya untuk menghadapi berbagai tantangan hidup (UPI, 2007: 423-425).

Tujuan dan Fungsi Pendidikan Seni:

1. Mengembangkan sensitivitas persepsi indriawi pada anak melalui pengalaman yang kreatif sesuai karakter dan jenjang perkembangan pada pendidikan.

2. Memberikan stimulus pada anak pada pertumbuhan ide-ide yang imajinatif dan dapat menemukan berbagai penemuan atau gagasan yang kreatif dalam memecahkan masalah artistik atau estetik melalui proses eksplorasi, kreasi, presentasi dan apresiasi sesuai minat dan potensi diri yang dimiliki anak di tiap jenjang pendidikan.
3. Mengintegrasikan pengetahuan dan keterampilan kesenian dengan disiplin ilmu lain yang serumpun atau tidak serumpun melalui berbagai pendekatan keterpaduan yang sesuai karakter keilmuannya.

4. Dapat mengembangkan kemampuan untuk berapresiasi seni dalam konteks sejarah dan dapat menghargai berbagai macam budaya lokal juga global, sebagai sarana pembentukan saling toleransi dan demokratis dalam masyarakat yang majemuk.

(sumber: http://seputarpengertian. blogspot.co.id/2017/02/pengertianpendidikan-seni-serta-tujuannya.html, diakses tanggal 26 Maret 2017).

Bila dicermati dari program pemerintah mengenai dunia pendidikan tahun 2005-2025 dimana pemerintah melakukan pentahapan pendidikan dengan rangkaian sebagai berikut:

- Tahun 2005 - 2010 adalah pentahapan modernisasi dan peningkatan kapasitas pendidikan.

- Tahun 2010 - 2015, peningkatan kapasitas dan mutu pendidikan.

- Tahun 2015 - 2020, peningkatan mutu, relevansi dan kompetitif.

- Tahun 2020 - 2025, pematangan.

Maka langkah-langkah yang dilakukan oleh pemerintah untuk mewujudkan itu adalah (1) meningkatkan dan memeratakan partisipasi atau akses pendidikan maksudnya untuk menciptakan keadilan dan pendidikan dengan memeratakan dan meningkatkan akses pendidikan; (2) mewujudkan pendidikan masyarakat yang bermutu, berdaya saing, relevan dengan kebutuhan masyarakat mengandung makna bahwa output pendidikan yang dihasilkan haruslah bermutu, relevan, dan berdaya saing; (3) mewujudkan sistem pengelolaan pendidikan yang efektif, efisien, akuntabel dengan menekankan pada peranan desentralisasi dan otonomi pendidikan pada setiap jenjang pendidikan di masyarakat dan meningkatkan citra publik.

Bila dilihat program yang dicanangkan oleh pemerintah diatas maka pendidikan seni memberikan sumbangsih yang sangat penting terutama dalam hal mengembangkan kreativitas dan inovasi agar daya saing yang diharapkan dapat terwujud. Seperti telah dijelaskan diatas bahwa salah satu tujuan dan fungsi pendidikan 
seni adalah membangun stimulus pada peserta didik agar tercipta inovasi-inovasi baru dan membangun kreativitas untuk memecahkan permasalahan yang terjadi baik di masyarakat, negara, dan bangsa ini. Pendidikan seni juga memberikan kemampuan untuk mengintegrasikan pengetahuan dan keterampilan kesenian dengan disiplin ilmu lain yang serumpun atau tidak melalui berbagai pendekatan.

Pendekatan-pendekatan yang dilakukan bisa berupa pendekatan secara vertikal maupun horisontal sehingga solusi yang diberikan akan relevan dengan permasalahan yang terjadi. Melihat hal ini dapat dikatakan bahwa pendidikan seni memiliki korelasi yang kuat dengan pentahapan pendidikan yang dicanangkan oleh pemerintah. Kemampuan untuk melakukan inovasi dan kompetitif melalui kreativitas seni akan sangat membantu dalam hal menuangkan ideide kreatif ditambah pendekatan-pendekatan berbasis multidisplin yang dilakukan akan menambah kekuatan dalam membangun daya saing yang diharapkan. Untuk itu diharapkan adanya berbagai usaha untuk melakukan sinergi pendidikan seni dengan berbagai pihak terkait. Menurut Limbeng (2010), beberapa hal yang perlu dilakukan secara sinergi dengan instansi terkait, yaitu dengan bidang pendidikan adalah dalam pelaksanaan :

- Optimalisasi pendidikan kesenian di sekolah-sekolah formal, maupun informal.

- Bersinergi merancang kurikulum untuk mewujudkan paradigma pendidikan seni yang berwawasan Indonesia.

- Menggali pola alternatif pendidikan seni berbasis tradisi Indonesia.

- Peningkatan apresiasi terhadap sejarah seni di tanah air.

- Mengembangkan tradisi kritik dan riset seni.

- Perluasan pendidikan formal seni untuk kawasan timur Indonesia.

\subsection{Praktek Diskursif.}

Perlunya penentuan arah kebijakan dalam pendidikan khususnya pendidikan dibidang seni, karena tantangan-tantangan yang dihadapi pendidikan seni tidaklah sederhana. Menurut Kusbiantoro (2015), problem yang dihadapi oleh penyelenggara pendidikan tinggi seni rupa dan desain adalah kehilangan "rasa" atau "roh" yang menjadi pembeda utama dari penyelenggara pendidikan tinggi non seni rupa. Buktinya saat ini para pejabat, dosen dan staff di perguruan tinggi seni rupa dan desain tidak lagi punya banyak waktu untuk berkesenian dan lebih sibuk dengan pekerjaan formalisme akademik dan administratif; menyiapkan borang akreditasi, sertifikasi, kenaikan pangkat dan lain sebagainya. Beratnya tuntutan pekerjaan administratif membuat banyak perguruan tinggi seni rupa dan desain terjebak pada rutinitas administratif dan bukan lagi berpijak pada penciptaan atmosfer poetik yang menjadi kekhasannya.

Menurut Soeteja (2011), masalah pendidikan seni rupa di sekolah umum dapat dikategorikan dalam beberapa aspek sebagai berikut: (1) Guru; (2) Siswa; (3) Sarana dan Prasarana; (4) Kurikulum dan Materi Pembelajaran; (5) Administrasi Sekolah dan (6) Orang Tua dan Masyarakat. Dari keenam aspek tersebut, hal paling krusial biasanya ada pada tiga aspek yaitu aspek guru (SDM), siswa, serta sarana dan prasarana. Aspek yang paling dominan atau utama adalah guru yang menjadi penentu "sukses" tidaknya proses pembelajaran seni di sekolah. Berdasarkan pengalaman dalam melakukan advokasi pembelajaran seni rupa di berbagai daerah di Indonesia, masalah "keterabaian" atau "keterpinggirkan" mata pelajaran seni merupakan persoalan yang sering kali dikeluhkan guru. Dianggap sepele atau tidak penting merupakan keluhan yang berkali-kali muncul dan bahkan dianggap sebagai beban kurikulum. Mata pelajaran ini dianggap penting hanya jika sekolah diwajibkan untuk mengikuti kegiatan seperti festival dan lomba seni siswa nasional dan sejenisnya.

Sisi orang tua dan masyarakat masih melihat seni hanya sekadar dari unsur estetika dan prestise belaka. Mereka lebih suka anak-anaknya belajar seni Barat, seperti piano, tari Ballet, dibandingkan seni-seni lokal Indonesia. Mereka kurang melihat "seni" secara holistik atas keterkaitannya dengan sistem masyarakat. Padahal, dengan melakukan atau mengapresiasi kesenian lokal, seni miliknya sendiri akan tersirat nilai-nilai sosial dan juga pendidikan. Selain itu, orang tua siswa masih banyak yang ikut campur hingga ke masalah teknis yang akhirnya tidak mendidik. Sebagai contoh, dalam pergelaran pertunjukan Drama Tari, tidak semua anak siswa mendapatkan peran yang harus berbusana serba glamor. 
Tetapi orang tua siswa bersikeras anaknya harus mengenakan busana glamor, kendatipun memerankan gadis miskin yang serba kekurangan, dan lain sebagainya. Oleh karenanya peran para pendidik seni menjadi sangat penting untuk melakukan berbagai strategi dalam menerapkan materi seni tradisional sehingga dapat membangkitkan minat para anak didik untuk menyenangi seni tradisional dengan metode atau cara-cara yang tepat guna (Caturwati, 2013).

\subsection{Praktik Sosial Budaya}

Indonesia sebagai salah satu negara kepulauan terbesar di dunia dengan jumlah pulau 13.644 pulau dengan jumlah suku bangsa yang mendiami pulau-pulau yang ada di Indonesia adalah sebanyak 1340 suku bangsa. Jumlah suku bangsa yang besar ini membuat Indonesia sangat dikenal dengan keanekaragaman seni dan budaya yang dimiliki. Kekayaan akan keanekaragaman seni dan budaya memungkinkan banyaknya muncul karya-karya seni yang luar biasa dari tangan-tangan kreatif anak bangsa sehingga perlu adanya upaya untuk melestarikan kekayaan bangsa tersebut.

Keanekaragaman dan kekayaaan seni dan budaya yang dimiliki oleh bangsa Indonesia merupakan sebuah realita yang harus disadari oleh seluruh masyarakat Indonesia. Kebanggaan memiliki kekayaan seni dan budaya harus terus dilestarikan. Pelestarian terhadap seni dan budaya tersebut dilakukan dengan cara melakukan transmisi, transaksi, dan transformasi. Transmisi berarti kegiatan mengirimkan dan menyebarkan pesan dari satu generasi ke generasi selanjutnya tentang sesuatu yang menjadi kebiasaan dan sulit diubah. Transmisi budaya merupakan cara sekelompok orang dalam suatu masyarakat atau budaya untuk menyampaikan sejumlah pengetahuan atau pegangan dalam meneruskan budaya kepada generasi atau sekelompok masyarakat yang lain dalam rangka untuk melestarikan budaya.

Transmisi budaya tidak hanya menyampaikan suatu yang material melainkan yang terpenting adalah penyampaian nilai-nilai yang dianggap baik yang telah menjadikan pedoman dalam masyarakat. Bentuk-bentuk transmisi budaya yaitu akulturasi, enkulturasi, dan sosialisasi (Fauziah, 2012). Transaksi budaya merupakan dialog antar budaya yang dilakukan oleh seseorang atau sekelompok orang dengan orang atau sekelompok orang yang lain. Transformasi budaya diartikan sebagai suatu proses dialog terus menerus antara kebudayaan lokal dengan kebudayaan luar sampai dengan tahap tertentu membentuk suatu proses sintesa dengan berbagai wujud yang akan melahirkan format budaya yang mantap. Proses akhir yang diperoleh merupakan proses inkulturasi dan akulturasi.

Globalisasi yang terjadi akibat perkembangan ilmu pengetahuan dan teknologi memungkinkan transmisi, transaksi, dan transformasi budaya terjadi dengan sangat cepat. Hal ini memungkinkan karena dalam globalisasi terjadi pemadatan ruang dan waktu dimana segala keterbatasan yang sebelumnya terjadi kini sudah dihilangkan. Menurut Appadurai (1996), ada lima bentuk globalisasi yaitu :

1. Ethnoscapes: yaitu pergerakan manusia termasuk turis, imigran, pengungsi dan pebisnis-pebisnis melintasi batas negara.

2. Financescapes: yaitu aliran uang yang melintasi sekat-sekat Negara. Hal ini terjadi berkat pasar uang, tukar-menukar saham dan obligasi, dan pasar komoditas yang semakin sibuk antar negara setiap hari dan bahkan setiap detik.

3. Ideoscapes: yaitu, penyebaran gagasan dan ideologi politik yang mendunia.

4. Mediascapes: yaitu, penyebaran lintas budaya gambar-gambar media di layer komputer, koran, televisi, dan radio.

5. Technoscapes: yaitu, penyebaran teknologi ke seluruh penjuru dunia. Penemuanpenemuan bidang teknologi dapat dengan mudah diakses dengan menggunakan internet.

Melihat hal ini maka tentunya masyarakat dengan mudah dapat terus menerus melakukan transmisi, transaksi, dan transformasi budaya dengan masyarakat lain sehingga proses pertukaran budaya dengan cepat dapat terjadi.

\subsection{Analisa Kritis}

Paradigma pendidikan di Indonesia yang pada awalnya lebih menekankan pada sains, teknologi dan ekonomi ternyata memberikan dampak yang kurang baik bagi peserta didik. Siswa lebih mengagung-agungkan kecerdasan intelektual dan mengesampingkan moralitas. Pendidikan hanya untuk memenuhi hasrat pasar dan melupakan kearifan dan pengembangan 
karakter peserta didik. Dampak lain yaitu sikap toleransi, kepekaan terhadap rasa keindahan dan kemampuan untuk berimajinasi dan berkreasi semakin rendah. Nilai kompetitif yang dicanangkan oleh pemerintah lewat program pendidikan tahun 2005-2025 akan sulit tercapai. Sehingga perlu adanya upaya untuk meningkatkan hal ini.

Tawaran yang diberikan bidang seni dalam menghadapi permasalahan tersebut adalah dengan memberikan pengalaman etika dan estetika bagi yang menekuninya. Pendidikan seni sebagai sebuah tawaran dalam mengembangkan pengalaman etika dan estetika juga memiliki masalah tersendiri. Guru sebagai sumber daya manusia dalam pembelajaran merasa bahwa mata pelajaran seni di berbagai daerah di Indonesia sebagai mata pelajaran yang dianggap sepele atau tidak penting dan dianggap beban bagi kurikulum. Mata pelajaran seni diwajibkan hanya jika untuk mengikuti sebuah seremoni dan lomba seni saja. Selain itu, sarana dan prasarana yang kurang memadai dan keikutsertaan siswa yang rendah untuk mata pelajaran seni juga menjadi kendala. Sikap orang tua dan masyarakat juga menjadi pemicu semakin rendahnya keinginan siswa untuk belajar seni di sekolah.

Pentingnya pendidikan seni diberikan adalah karena dalam pendidikan seni melatih siswa untuk mengembangkan cipta, rasa, dan karsa. Berkarya, mengolah keterampilan yang dimiliki, melakukan inovasi dan invensi secara terus menerus sebagai buah dari cipta, rasa, dan karsa merupakan tujuan pendidikan untuk menjadi insan Indonesia yang kompetitif. Membangun sikap toleransi, mencintai keindahan, dan memiliki etika dalam pergaulan juga merupakan tujuan pendidikan seni. Globalisasi yang terjadi di seluruh jagat memberikan peluang yang sangat luas untuk lebih mengenal seni dan budaya Indonesia secara luas dan menyeluruh. Masyarakat sudah dapat mempelajari seni dan budaya di masing-masing daerah. Karya-karya seni yang dibuat juga sudah dapat diterima tidak hanya oleh masyarakat disekitarnya tetapi juga dapat diterima oleh masyarakat yang berbeda budaya.

Globalisasi membuat akulturasi dan inkulturasi terjadi dimana-mana sehingga pendekatan pendidikan seni juga diharapkan mampu mengakomodasikan hal ini. Paradigma pendidi- kan seni ke depan diharapkan mampu menggunakan berbagai pendekatan dimana peserta didik dapat menumbuhkembangkan pandangan dan sikap toleran terhadap keberagaman budaya yang ada di Indonesia. Pendidikan seni diharapkan menjadi mata kuliah yang wajib diberikan di perguruan tinggi agar mahasiswa memiliki sikap peka rasa, estetika, kreatif dan inovatif serta memiliki karakter yang adaptif terhadap perubahan dan memiliki etika dalam berkarya. Pendidikan seni bukan hanya pendidikan yang ada hanya karena kebutuhan lomba seni saja tetapi sudah menjadi kebutuhan sehari-hari. Menghadapi globalisasi yang terjadi, pendidikan seni diarahkan pada pendekatan multikultural sehingga bisa diterima oleh berbagai kalangan masyarakat.

Pendidikan seni dengan pendekatan multikultural harus memiliki keluwesan dan bergantung pada kemampuan peserta didik dan kondisi sosial budaya masyarakat setempat. Peran pendidik seni diharapkan tidak hanya memiliki pengetahuan seni lokal saja, tetapi juga memiliki pengetahuan tentang seni daerah lain sehingga mahasiswa memiliki pengetahuan yang lengkap tentang seni dan budaya dan toleransi dengan keberagaman.

\section{PENUTUP}

Paradigma pendidikan di Indonesia yang pada awalnya lebih menekankan pada sains, teknologi, dan ekonomi ternyata memberikan dampak yang kurang baik. Siswa lebih mengagung-agungkan kecerdasan intelektual dan mengesampingkan moralitas. Pendidikan hanya untuk memenuhi hasrat pasar dan melupakan kearifan dan pengembangan karakter peserta didik. Dampak lain yaitu sikap toleransi, kepekaan terhadap rasa keindahan dan kemampuan untuk berimajinasi dan berkreasi semakin rendah. Pendidikan seni menjadi sebuah jawaban terhadap permasalahan tersebut. Di sisi lain, pendidikan seni memiliki permasalahan tersendiri. Kurangnya guru, sarana prasarana, dan kurikulum yang mendukung merupakan kendala yang dihadapi oleh pendidikan seni. Selain itu, globalisasi yang akibat perkembangan ilmu pengetahuan dan teknologi telah memberikan dampak positif terhadap perkembangan seni dan budaya. Paradigma baru pendidikan seni terhadap perkembangan yang terjadi perlu di- 
canangkan. Paradigma pendidikan seni ke depan diharapkan mampu menggunakan berbagai pendekatan peserta didik dapat menumbuhkembangkan pandangan dan sikap toleran terhadap keberagaman budaya di Indonesia. Pendidikan seni diharapkan menjadi mata kuliah yang wajib diberikan di perguruan tinggi agar mahasiswa memiliki sikap peka rasa, estetika, kreatif dan inovatif serta memiliki karakter adaptif terhadap perubahan dan memiliki etika dalam berkarya. Pendidikan seni bukan hanya pendidikan yang ada hanya karena kebutuhan lomba seni saja tetapi sudah menjadi kebutuhan sehari-hari.
Menghadapi globalisasi yang terjadi, pendidikan seni diarahkan pada pendekatan multikultural sehingga bisa diterima oleh berbagai kalangan masyarakat. Pendidikan seni dengan pendekatan multikultural harus memiliki keluwesan dan bergantung pada kemampuan peserta didik dan kondisi sosial budaya masyarakat setempat. Peran pendidik seni diharapkan tidak hanya memiliki pengetahuan seni lokal saja, tetapi juga memiliki pengetahuan tentang seni daerah lain sehingga mahasiswa memiliki pengetahuan yang lengkap tentang seni dan budaya dan toleransi dengan keberagaman.

\section{DAFTAR PUSTAKA}

Appadurai,A.(1996). "Disjuncture and Difference in the Global Cultural Economy" from Modernity at Large. Cultural Dimensions of Globalization, Pp. 27-47.USA: University of Minnesota Press.

Caturwati, E.(2013, 10 April). Tantangan Masa Depan Pendidikan Seni dalam Pembentukan Karakter Bangsa. http://www.sagangonline.com/baca/kajian/198/tantangan-masa-depan-pendidikan-seni--dalam-pembentukan-karakter-bangsa, diakses tanggal 30 Maret 2017.

Elliot, David. J. (1995). Music Matters. New York: Oxford University Press

Fauziah, N.(2012, 7 Oktober). Transmisi budaya dan biologis serta awal perkembangan dan pengasuhan. http://nuyuyfauziah.blogspot.co.id/2012/10/ transmisi-budaya-dan-biologisserta.html, diakses tanggal 3 April 2017.

Hakim, R. (2012). Pembelajaran Seni Budaya di Era Global (Sebuah Tantangan Baru yang Dihadapi oleh Pendidik Seni). Prosiding ISLA FBS Universitas Negeri Padang, 296-299.

Kusbiantoro, K. (2015). Tantangan Pendidikan Seni Rupa dan Desain Indonesia Sebuah Refleksi tentang Eksistensi 1 Dekade FSRD UK Maranatha. Zenit, 2(2).

Limbeng, J.P.(2010, 28 Juni).Kesenian Indonesia dan Tantangan ke Depan. http://xeanexiero. blogspot.co.id/2010/06/kesenian-indonesia-dan-tanta, diakses tgl 29 Maret 2017.

Soeteja, Z.S.(2011, 17 Mei). Merevitalisasi Pendidikan Seni Rupa di Sekolah. http://zsoeteja.blogspot. co.id/2011/05/pendidikan-melalui-seni-kria.html, diakses 30/3/2017.

Soemardjo, J.(2000). Filsafat Seni. Bandung: Penerbit ITB

UPI, T. P. I. P. (2007). Ilmu dan Aplikasi Pendidikan Bagian III: Pendidikan Disiplin Ilmu. Bandung: PT. Imperial Bhakti Utama.

QSCC. (2002). The art. Year 1-10 Syllabus. Quensland: QSA Quensland. http://www.qsa.edu.au/ yrs1-10/kla/arts/pdf. 